\title{
Effects of a dry period on the limnological characteristics of a Mediterranean high mountain lake
}

\author{
Fátima García-Jurado, Francisco Jiménez-Gómez and Francisco Guerrero*
}

\author{
Departamento de Biología Animal, Biología Vegetal y Ecología \\ Campus de Las Lagunillas, s/n Universidad de Jaén 23071 Jaén, Spain. \\ *Corresponding author: fguerre@ujaen.es
}

Received: 26/3/10 Accepted: 25/11/10

\begin{abstract}
Effects of a dry period on the limnological characteristics of a Mediterranean high mountain lake

This investigation assesses the effects of a drought period on the physical and chemical properties and on the plankton community of a Mediterranean high mountain lake (Río Seco, Sierra Nevada, Spain). The study was performed over two consecutive years, 2005 and 2006. Both years were characterised by strong differences associated with rainfall patterns. The first year was extremely dry and had rainfall values far below the mean annual average of $813 \mathrm{~mm}$ that has been observed over the previous twenty years. The results of the study confirm that the dissolved inorganic nitrogen:soluble reactive phosphorus ratio (DIN:SRP) showed notable differences throughout both study years, with a greater nitrogen limitation during 2005 . The ratio of total biovolume of autotrophic to heterotrophic organisms $(\mathrm{A}: \mathrm{H})$ also presented interannual differences. The A:H ratio was generally below 1 during 2005, whereas it was above this value in 2006. Therefore, the main plankton component was mesozooplankton in 2005 and phytoplankton in 2006. Ciliates and bacteria showed a mean biovolume significantly higher in 2005, whereas the biovolume of heterotrophic nanoflagellates was similar during both years. These results indicate a prevalent "top-down" control by zooplankton during the dry year and, on the contrary, a predominant "bottom-up" control during the wetter year as a consequence of the nutrient limitation of primary production.
\end{abstract}

Key words: High mountain lakes, drought, plankton community, nutrients.

\section{RESUMEN}

Efectos de un periodo de sequía sobre las características limnológicas de una laguna mediterránea de alta montaña

En este trabajo se evalúan los efectos de un periodo de sequía sobre las propiedades físicas y químicas y las comunidades planctónicas de una laguna mediterránea de alta montaña (Río Seco, Sierra Nevada, España). El estudio se extendió durante los meses estivales de 2005 y 2006. Ambos años mostraron marcadas diferencias en cuanto al nivel de precipitaciones, estando el primero caracterizado por una pronunciada sequía, con valores de precipitación muy inferiores a los valores medios anuales de $813 \mathrm{~mm}$ registrados en los últimos 20 años. Los resultados obtenidos mostraron cómo la disponibilidad de nutrientes en el agua, expresada a través de la razón entre nitrógeno inorgánico disuelto y fósforo soluble reactivo (DIN:SRP), experimentó notables diferencias entre los dos años de estudio, mostrando una limitación por nitrógeno más acentuada durante el verano de 2005. La razón entre biovolumen total de organismos autótrofos y heterótrofos (A:H) también mostró diferencias entre ambos años. Esta razón fue generalmente inferior a uno en 2005 y superior a este valor en 2006, siendo el mesozooplancton el componente principal del plancton en 2005 y el fitoplancton en 2006. Ciliados y bacterias mostraron un biovolumen medio significativamente mayor en 2005, mientras que el biovolumen de heterótrofos nanoflagelados fue prácticamente constante en ambos años. Estos resultados, indican un predominio del control de tipo "top-down" del zooplancton en el año más seco, mientras que el control fue predominantemente de tipo "bottom-up” en el año más húmedo, a consecuencia de una mayor limitación de nutrientes.

Palabras clave: Lagunas de alta montaña, sequía, comunidad planctónica, nutrientes. 


\section{INTRODUCTION}

The growth of the human population is causing environmental changes on local and global scales. High mountain areas have generally been uninfluenced by agricultural and forestry practices, and they remain relatively unaffected by human impacts. However, recent studies have shown that even areas removed from human influence in Europe are undergoing important changes (see, e.g., Battarbe et al., 2001; AgustíPanareda \& Thompson, 2002; Catalán et al., 2002; Rose et al., 2002).

High mountain lakes have traditionally been of particular research interest because, apart from their isolation from anthropogenic influence, they are subjected to extreme meteorological conditions (Schindler et al., 1990). Thus, small high mountain lakes subjected to severe physical conditions have long been recognised as unique and valuable inland-water ecosystems. In these ecosystems, interactions between local and regional features, and between abiotic and biotic variables, make it difficult to identify the key factors that control the lake response (MoralesBaquero et al., 2006a). Indeed, physical and hydrological properties are directly influenced by meteorological forces. This fact produces consequences for the abundance and succession of the organisms that inhabit such lakes (Straile, 2000). Furthermore, properties linked to a fluctuating climate are responsible for their relatively simple biological communities.

Because climatic models predict more frequent and intense droughts for Europe (Planton et al., 2008), additional research on the effects of drought on the dynamics and composition of plankton in aquatic systems is required. For this purpose, it is necessary to improve the knowledge of the physical and chemical environment and, moreover, to refine current descriptions of plankton community structure in response to hydrodynamic changes associated with extreme physical conditions (García-Jurado et al., 2007). In this context, the high mountain lakes of Sierra Nevada National Park (southern Spain) have suffered three severe drought periods in the last twenty years $(1995,1999$, and 2005). The main purpose of this study was to assess the effects of a dry period (2005) in contrast to a wetter hydrological year (2006) on physical and chemical features and also on the plankton community of Río Seco, a high mountain lake.

\section{METHODS}

\section{Study site}

Río Seco is a small (0.4 ha) high mountain lake located in the Sierra Nevada mountains (southern Spain) at $3020 \mathrm{~m}$ a.s.l on siliceous bedrock. The lake is glacial in origin and is generally covered by ice from October-November until MayJune. It is located in a watershed covered by alpine meadows and with temporary inflows that drain water from the basin (Pulido-Villena et al., 2005). It is considered an oligo-mesotrophic lake (Pérez-Martínez et al., 2007) and has traditionally been limited by nitrogen (Morales-Baquero et al., 2006b). The inputs of allochthonous nutrients take place in the ice-melt period (CruzPizarro \& Carrillo, 1996) and by atmospheric deposition throughout the year (Morales-Baquero et al., 2006b). It is an open lake that receives water from a small superficial flow and includes a small spillway. These features disappear as summer progresses.

The plankton community of the lake is simple. Like other mountain aquatic systems, it is characterised by reduced biological diversity (MoralesBaquero et al., 1992). The phytoplankton community is dominated by nanoplanktonic species (Morales-Baquero et al., 2006a) that can colonise easily, for example, Korshikoviella gracilipes (Sánchez-Castillo et al., 1989). The zooplankton community is dominated by the calanoid copepod Mixodiaptomus laciniatus and the cladoceran Daphnia pulicaria (Pérez-Martínez et al., 2007). Río Seco also exhibits littoral vegetation composed of bryophytes. Fish communities are absent.

\section{Field sampling}

Field samples were collected each month during the ice-free period of two consecutive years, 
2005 and 2006. During this period, lake depth was registered with a portable HONDEX PS-7 depth gauge. Historical water depths were compiled from the literature (Morales-Baquero et al., 1995; 1999; 2006a; Pérez-Martínez et al., 2007; Pulido-Villena et al., 2003; 2005), and rainfall data were provided by the Cetursa company. Samples for determination of physicochemical and biological variables (bacterial, heterotrophic nanoflagellates, pico-nanophytoplankton, ciliates and large phytoplankton) were taken at the deepest point of the lake and at $0.5 \mathrm{~m}$ intervals with a 2 L Van Dorn bottle. At the same point, pelagic zooplankton samples were collected from vertical tows with a plankton net of $63 \mu \mathrm{m}$ mesh size. In addition, at each sampling date, measurements of $\mathrm{pH}$, conductivity and dissolved oxygen were performed with a multiparametric Yellow Spring Instruments probe. The thermal structure was monitored by thermistor chains $\left(\mathrm{HOBO}_{\mathbb{}}\right.$ $\mathrm{H} 20-001)$ located at different and representative sites in the lake during ice-free periods of 2005 and 2006. These thermistors collected data continuously and averaged hourly values. Fluorescence data were recorded with a field fluorometer (Aquafluor Turner Design) and later converted to chlorophyll- $a$ concentration with a calibration curve previously obtained in situ.

\section{Chemical Analysis}

Samples for total phosphorus (TP) and total nitrogen (TN) were directly analysed from unfiltered water samples according to APHA methods (1995). Subsamples were filtered for the analysis of dissolved phosphate (SRP, Murphy \& Riley 1962), nitrate $\left(\mathrm{NO}_{3}^{-}\right.$, APHA 1995), nitrite $\left(\mathrm{NO}_{2}^{-}\right.$, Shinn 1941) and ammonia $\left(\mathrm{NH}_{4}^{+}\right.$, Rodier 1989) and for the volumetric determination of the total alkalinity (Metrohm 716 DMS). Dissolved inorganic nitrogen (DIN) was calculated as the sum of the concentrations of $\mathrm{NO}_{3}^{-}, \mathrm{NO}_{2}^{-}$, and $\mathrm{NH}_{4}^{+}$.

\section{Plankton abundance and biovolume}

The counts and volume measures of bacteria and heterotrophic nanoflagellates (HNF) were performed in samples fixed with glutaraldehyde
(2\% f.c.), which were stained with DAPI $\left(0.1 \mu \mathrm{g} \mathrm{mL}^{-1}\right.$ f.c. $)$, filtered onto $0.2 \mu \mathrm{m}$ pore-size polycarbonate filters and analysed by epifluorescence microscopy (Porter \& Feig, 1980). Five images per sample were taken and processed using the free image processing system UTHSCSA Image Tool 3.00. Individual biovolume was calculated according to Massana et al. (1997). Unstained subsamples were cryogenised and processed with a Coulter Elite flow cytometer to analyse the autotrophic pico-nanoplankton. Larger phytoplankton and ciliates were preserved in situ with Lugol (2 \% f.c.) and analysed using an inverted microscope with image analysis techniques following Utermöhl (1958).

Zooplankton samples were fixed in situ with formaldehyde (4\% f.c.) and analysed in the laboratory with a stereomicroscope equipped with a Leica digital camera. Biovolume was estimated from approximately cylindrical, elliptical or spherical forms by means of two-dimensional parameters obtained by image analysis of the recorded pictures.

\section{Statistical Analysis}

Data for statistical analysis were tested for homogeneity of variance (Kolmogorov-Smirnov test). When necessary, data were log transformed to satisfy the normality assumption. To explore the relationships between abiotic and biotic variables, a Pearson correlation was performed. A Kruskal-Wallis test for data having heterogeneous variance and a t-test were used to detect significant differences $(p<0.05)$. All statistical analyses were performed using STATISTICA 7.0.

\section{RESULTS}

\section{Physicochemical variables and nutrient availability}

During the last twenty years, high mountain lakes of the Sierra Nevada National Park have experienced three severe droughts, in 1995, 1999 and 2005. In 2005, the first year of our study, annual accumulated rainfall was less than $400 \mathrm{~mm}$ (Fig. 1a). However, the second study year (2006) 
(a)

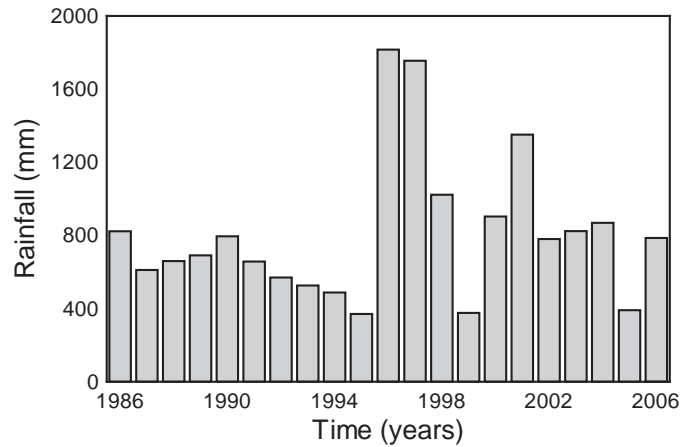

(b)

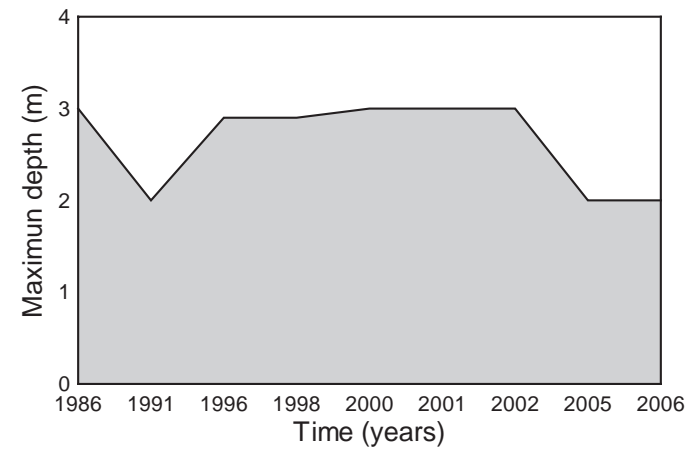

(c)

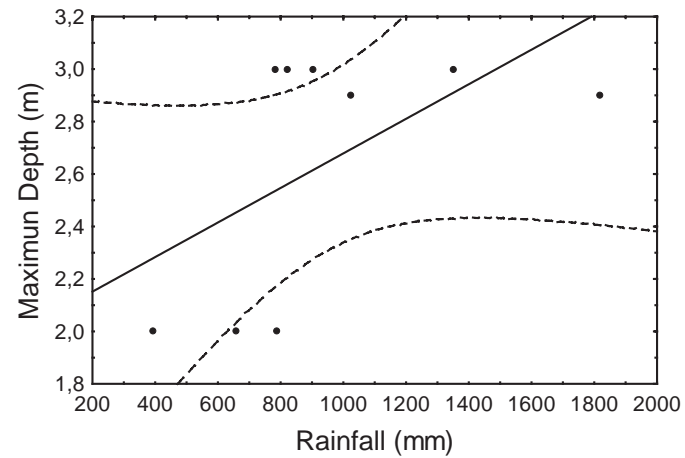

Figure 1. Interannual variability of $(a)$ accumulated annual rainfall and $(b)$ maximum water depth in Río Seco. Scatterplot of maximum lake depth and accumulated rainfall for the period 1986-2006 (c). Variabilidad interanual de (a) precipitación anual acumulada y (b) profundidad máxima de Río Seco. Correlación entre la profundidad máxima del lago y la precipitación anual acumulada en el periodo 1986-2006 (c).

was characterised by an annual accumulated rainfall value $(786.3 \mathrm{~mm})$ similar to the average reported for the area over the last twenty years $(812.9 \mathrm{~mm})$. Contrary to expectation, Río Seco exhibits only slight changes in the water column depth during such dry periods. In fact, over the last decade, a reduction in depth of only $1 \mathrm{~m}$ was observed (Fig. 1b). Accordingly, annual accumulated rainfall and maximum depth were not significantly correlated $(r=0.57 ; p>0.05)$ (Fig. 1c).
Data obtained from thermistors showed no differences in water temperature during the study period between surface and bottom, so no thermal stratification occurred (Fig. 2). Oxygen concentrations were high throughout the study period, with values close to saturation (mean saturation percentage of $80 \%$ and $100 \%$ for 2005 and 2006, respectively). Conductivity values ranged from 12 and $22 \mu \mathrm{S} \mathrm{cm}^{-1}$ and al-

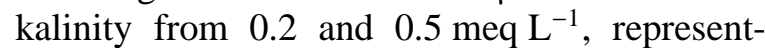
ing a considerable bicarbonate buffer capacity ( $\mathrm{pH}$ ranged between 6.8 and 6.9).
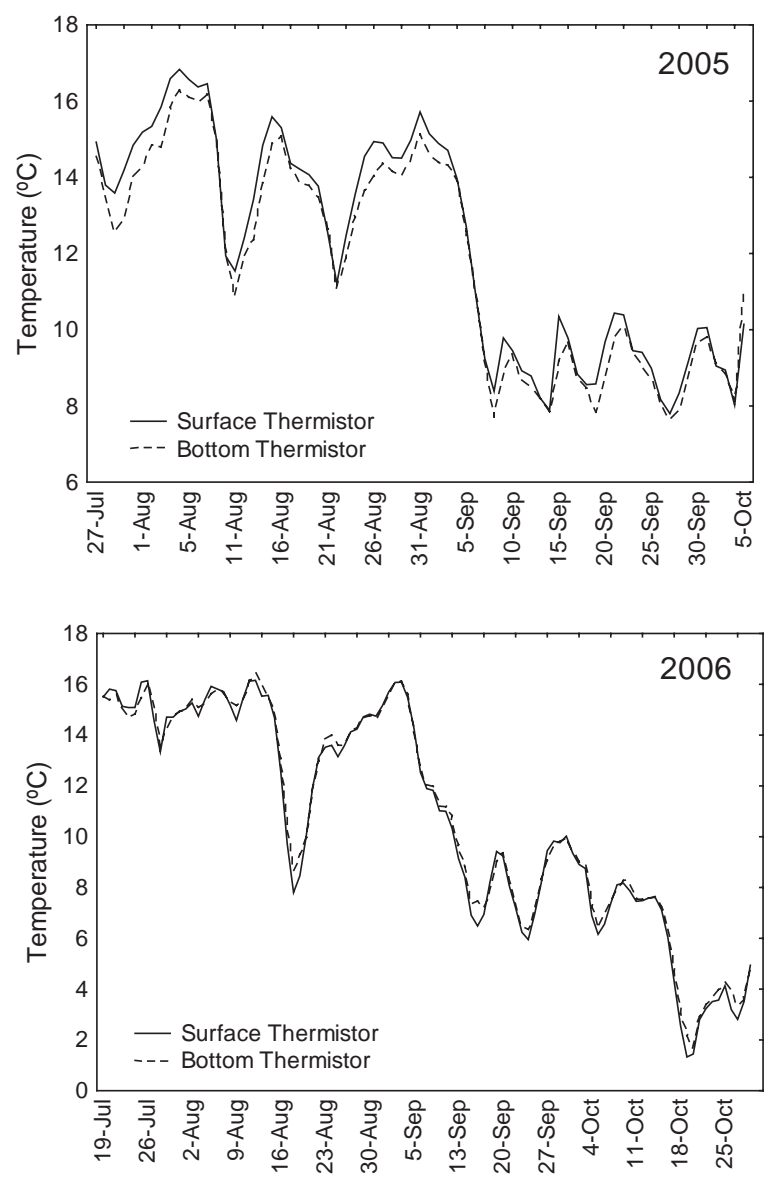

Figure 2. Diel variations in lake water temperature during the ice-free period (from July to October 2005 and 2006) in Río Seco. Solid line: temperature registered by the surface thermistor. Dashed line: temperature registered by the bottom thermistor. Variaciones diarias en la temperatura del agua del lago durante los periodos libres de hielo (desde julio a octubre de 2005 y 2006) en Río Seco. La línea continua indica la temperatura registrada por el termistor de superficie y la línea discontinua la temperatura registrada por el termistor de fondo. 

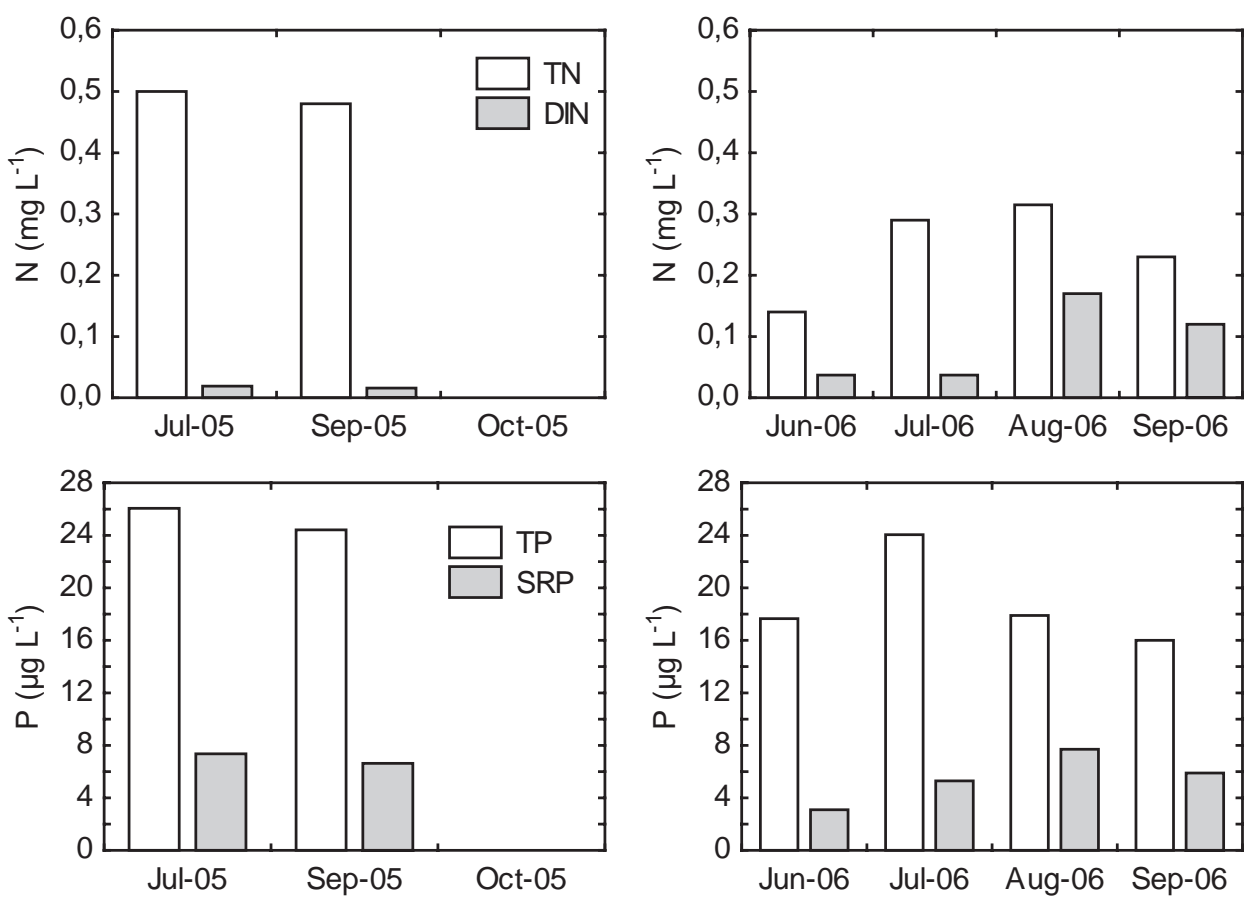

Figure 3. Mean nutrient concentrations for the water column. Total phosphorus (TP; $\mu \mathrm{g} \mathrm{L}^{-1}$ ), soluble reactive phosphorus (SRP; $\mu \mathrm{g} \mathrm{L}^{-1}$ ), total nitrogen (TN; $\mathrm{mg} \mathrm{L}^{-1}$ ) and dissolved inorganic nitrogen (DIN; $\mathrm{mg} \mathrm{L}^{-1}$ ), in summer of 2005 and 2006 . Concentración media de nutrientes en la columna de agua. Fósforo total $\left(T P ; \mu g L^{-1}\right)$, fósforo soluble reactivo $\left(S R P ; \mu g L^{-1}\right)$, nitrógeno total (TN; $m g L^{-1}$ ) y nitrógeno inorgánico disuelto (DIN; $\left.\mathrm{mg} \mathrm{L}^{-1}\right)$, en los veranos de 2005 y 2006.

Intra- and interannual variations in integrated nutrient concentrations in the water column are shown in figure 3 . Higher values of $\mathrm{TN}$ were reached in 2005 than in 2006. Especially low DIN values were measured during the first study year ( $4 \%$ of $\mathrm{TN})$, whereas DIN represented an average of $37 \%$ of TN in 2006. During the entire study period, $\mathrm{NO}_{3}^{-}$was the only fraction contributing to DIN. Highest values of TP were registered in July and September 2005 and July 2006. SRP represented an increasing fraction of TP during summer 2006, whereas it was fairly constant during 2005. TN:TP mass ratio did not show significant differences between years ( $t-$ test; $p<0.05$ ), with mean average values close to 19 and 13 during the ice-free periods of 2005 and 2006, respectively (Fig. 4). DIN:SRP ratio varied strongly between years and showed significantly higher values in 2006 than 2005 (t-test; $p<0.05$; DIN:SRP = 15.3). In fact, DIN:SRP was lower than 3 in 2005, a value that indicated $\mathrm{N}$ deficiency of the phytoplankton communities (Fig. 4).

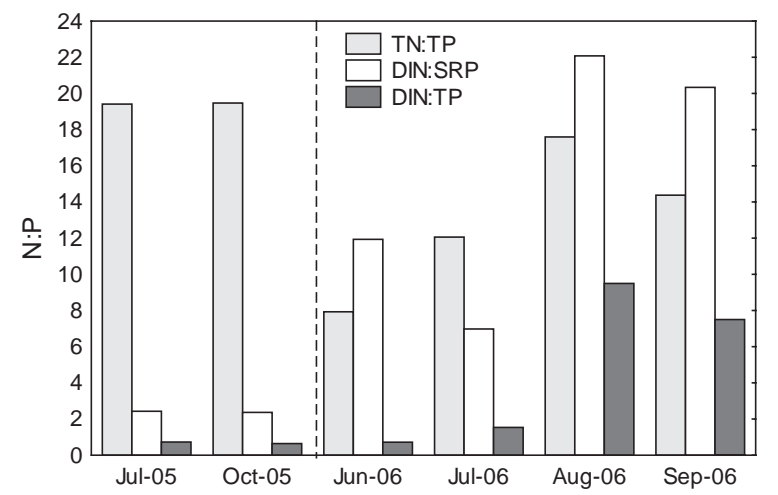

Figure 4. Nitrogen: phosphorus mass ratio in Río Seco during 2005 and 2006. Razón másica de nitrógeno:fósforo en Río Seco durante 2005 y 2006.

\section{Plankton community}

Mean chlorophyll- $a$ concentration was $0.22 \mu \mathrm{g}$ $\mathrm{L}^{-1}( \pm 0.07)$ in 2005 and $0.26 \mu \mathrm{g} \mathrm{L}^{-1}( \pm 0.05)$ in 2006 and exhibited higher values near the lake bottom until midsummer, whereas a sub- 
(a)
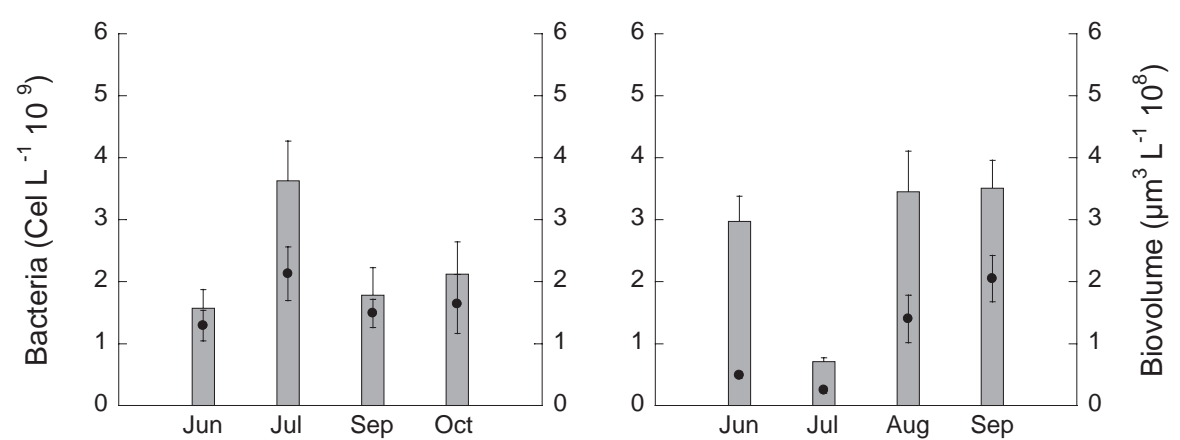

(b)
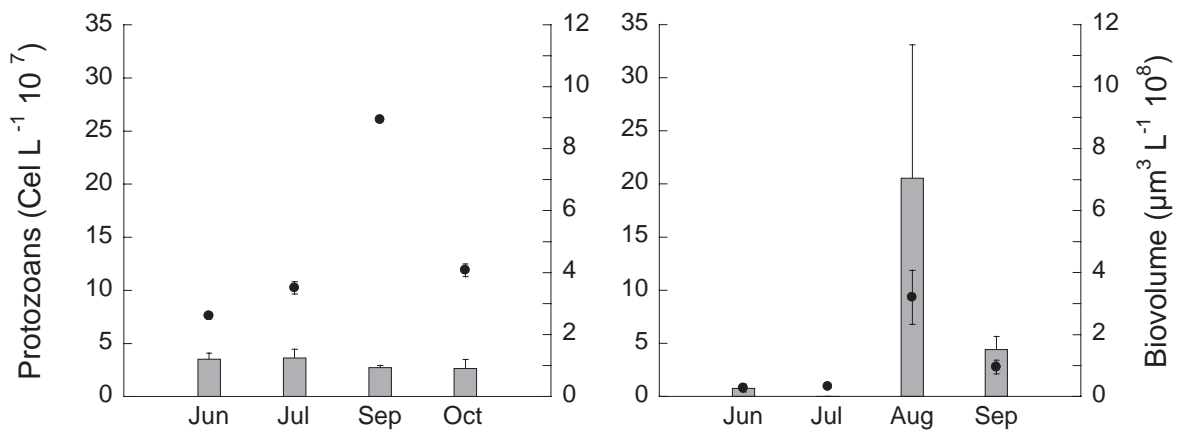

(c)
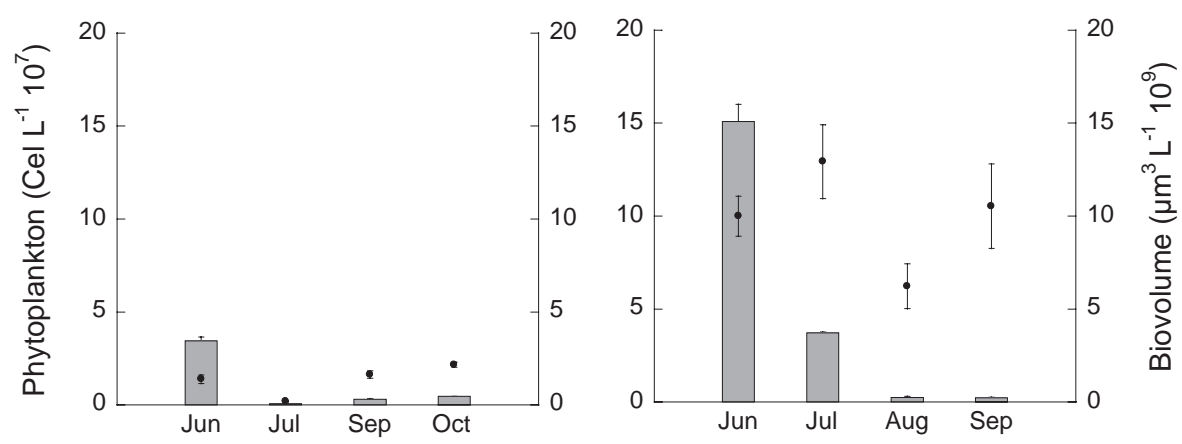

(d)
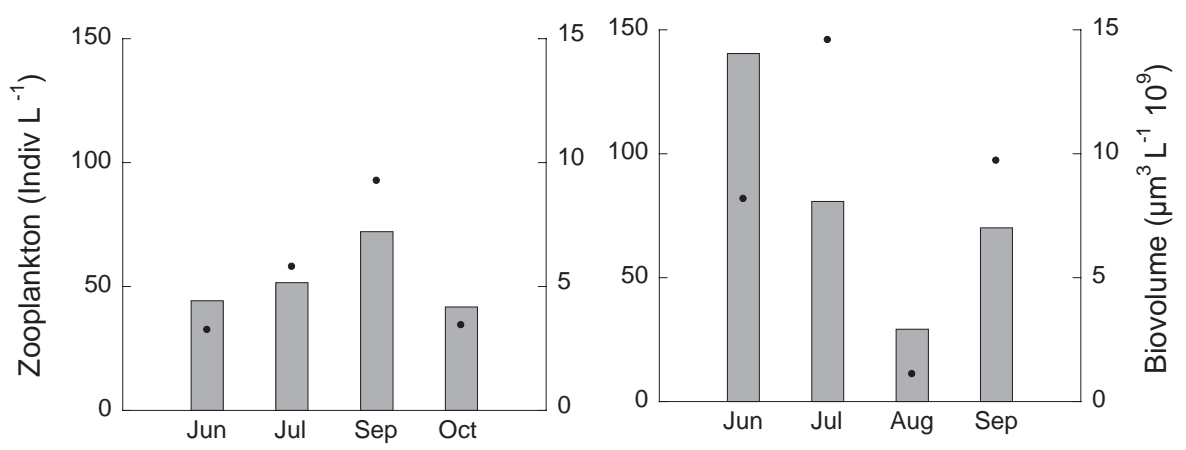

Figure 5. Intra- and interannual variation in the abundance (vertical bars) and biovolume (plots) of (a) bacteria; (b) protozoans (HNF plus ciliates); (c) phytoplankton and (d) zooplankton in Río Seco during summers of 2005 and 2006. Variaciones intra e interanuales en la abundancia (barras verticales) y biovolumen (puntos) de (a) bacterias; (b) protozoos (HNF más ciliados); (c) fitoplancton y (d) zooplancton en Río Seco durante los veranos de 2005 y 2006. 
superficial maximum was observed during the late period of the season (data not shown). No differences in chlorophyll-a concentration between years were observed (t-test; $p<0.05$ ). Temporal changes in the abundance and biovolume of bacterioplankton, protozoans [heterotrophic nanoflagellates and ciliates], phytoplankton and zooplankton are shown in figure 5. During the ice-free period of 2005, the abundance of bacteria reached maximum values in July. The abundance of protozoans was highest in June and July. Phytoplankton abundance reached its highest values in early summer and decreased over the ice-free period.

\section{(a)}

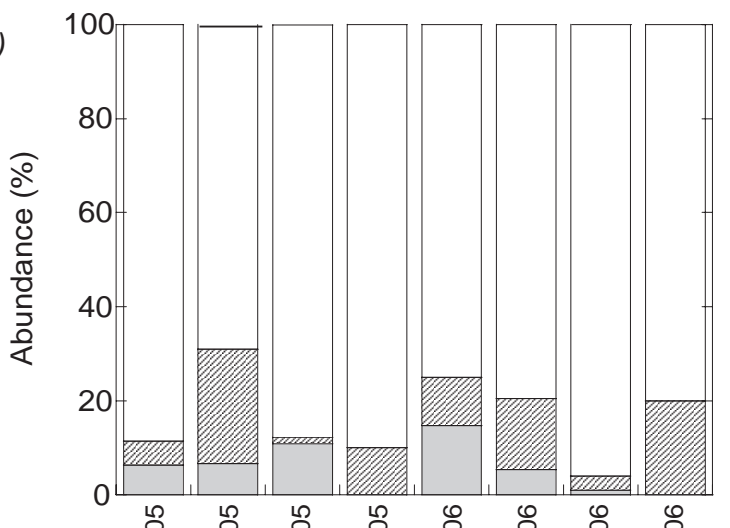

(b)

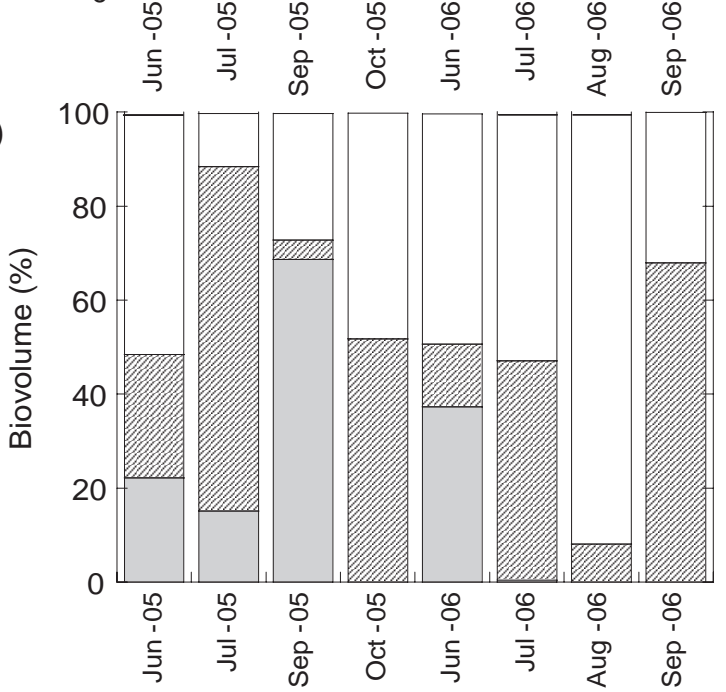

Figure 6. Percentage of Mixodiaptomus laciniatus (white), Daphnia pulicaria (lined) and other zooplankton species (gray) in terms of abundance $(a)$ and biovolume $(b)$. Porcentaje de Mixodiaptomus laciniatus (blanco), Daphnia pulicaria (rayado) y otras especies de zooplancton (gris) en términos de abundancia (a) y biovolumen (b).
However, zooplankton abundance reached its maximum value in September. The biovolume of these groups showed a trend similar to that of abundance, except that protozoans reached higher values in September owing to the presence of large-sized ciliates. In summer 2006, the abundance and biovolume of bacteria were constant over the summer with the exception of July, when minimum values were observed (Fig. 5). Protozoans exhibited maximum values of abundance and biovolume in August. Phytoplankton and zooplankton abundances decreased throughout the summer, but biovolume did not fit this pattern owing to the presence of very large individuals during the ice-free period. During the period studied, the zooplankton community was dominated by two species, the calanoid copepod Mixodiaptomus laciniatus and the cladoceran Daphnia pulicaria. This community was numerically dominated by the copepod $M$. laciniatus. This species represented more than $70 \%$ of the total abundance, especially during the early and late summer of 2005 and 2006 (Fig. 6). However, in terms of total biovolume, D. pulicaria $(8 \times$ bigger than $M$. laciniatus) dominated the zooplankton community during the early and late summer of both years and represented more than $50 \%$ of total zooplankton biovolume. Other zooplankton species such as Diaptomus cyaneus, Acanthocyclops vernalis and Chydorus sphaericus also

Table 1. Autotrophic:Heterotrophic ratio $(\mathrm{A}: \mathrm{H})$ and percentage of biovolume of bacteria (B), phytoplankton (Phy), zooplankton (Zoo), heterotrophic nanoflagellates (HNF) and ciliates (Cil) with respect to the total biovolume. Razón biovolumen autótrofos: biovolumen heterótrofos $(A: H)$ y porcentaje de biovolumen de bacterias (B), fitoplancton (Phy), zooplancton (Zoo), nanoflagelados heterótrofos (HNF) y ciliados (Cil), respecto al biovolumen total.

\begin{tabular}{lccrccc}
\hline & \multicolumn{5}{c}{ \% Total Biovolume } \\
\hline & A:H & \% B & \% Phy & \% Zoo & \% HNF & \% Cil \\
\cline { 2 - 7 } jun-95 & 0.38 & 2.6 & 27.6 & 64.7 & 1.7 & 3.5 \\
jul-05 & 0.03 & 3.4 & 3.0 & 88.4 & 1.1 & 4.1 \\
sep-05 & 0.16 & 1.2 & 13.6 & 77.6 & 0.5 & 7.0 \\
oct-05 & 0.54 & 2.7 & 35.0 & 55.7 & 1.0 & 5.6 \\
jun-06 & 1.21 & 0.3 & 54.8 & 44.8 & 0.1 & 0.0 \\
jul-06 & 0.88 & 0.1 & 46.9 & 52.9 & 0.0 & 0.1 \\
aug-06 & 3.96 & 1.8 & 79.8 & 14.3 & 4.1 & 0.0 \\
sep-06 & 1.05 & 1.0 & 51.2 & 47.3 & 0.5 & 0.0 \\
\hline
\end{tabular}


made noteworthy contributions to total zooplankton biovolume in September 2005 and June 2006.

The ratio of total biovolume of autotrophic to heterotrophic organisms (A:H) showed differences among years (Table 1). The A:H ratio was always less than 1 during the ice-free period of 2005 but was much greater than 1 during the summer of 2006 (average values of 0.2 and 1.8, respectively), except in July 2006. Planktonic fractions having major biovolume were mesozooplankton for 2005 and phytoplankton in 2006. Ciliates and bacteria exhibited significantly higher mean biovolume in 2005 , whereas HNF biovolume was similar during both study years (t-test; $p<0.05)$.

Pearson correlation analysis carried out with physical, chemical and biological variables included in the present study revealed differences between the summers of 2005 and 2006. In 2005, SRP and DIN were positively correlated $(r=0.98 ; p<0.05)$. Abundance of phytoplankton and ciliate biovolume were also significantly and positively correlated $(r=0.86$; $p>0.05$ ). Other significant positive correlations were found between HNF abundance and bacteria biovolume $(r=0.97 ; p<0.05)$ and between ciliate abundance and zooplankton biovolume $(r=0.95 ; p<0.05)$. In 2006, bacterial abundance and biovolume were positively correlated with the temperature $(r=0.94$ and $r=0.93 ; p<0.05$, respectively), and also with biovolume of zooplankton and phytoplankton $(r=0.98)$. On the other hand, zooplankton abundance and SRP showed a negative correlation $(r=-0.99 ; p<0.05)$.

\section{DISCUSSION}

Droughts represent extreme climatic conditions. Relatively lower rainfall and higher-than-average temperatures associated with droughts have drastic effects on aquatic ecosystems (Villar-Argáiz et al., 2002). In fact, climatic factors such as temperature (Sommaruga-Wögrath et al., 1997), precipitation, and duration of ice-free periods (Park et al., 2004) drastically affect the biotic activity and abiotic characteristics of high moun- tain lakes. However, despite the sharp decrease in the annual accumulated rainfall registered for the Sierra Nevada during 1995, 1999 and 2005, the water column depth in Río Seco remained rather constant. In fact, this result is consistent with previous findings that water storage is quite stable over years, with maximum depth ranging from 2 to $3 \mathrm{~m}$ (Morales-Baquero et al., 1995; 1999; 2006a; Pulido-Villena et al., 2005; PérezMartínez et al., 2007). In contrast, a nearby lake (La Caldera) is much more dependent on rainfall patterns than Río Seco (see, e.g., PulidoVillena, 2004; García-Jurado, 2010; de Vicente et al., 2010a). Although La Caldera and Río Seco experience the same Mediterranean climate, differences in catchment size and sill height make Río Seco much more independent of rainfall patterns (de Vicente et al., 2010a).

The higher external nutrient loading from the catchment area is the most important reason for the higher trophic state of Río Seco compared to that of other nearby lakes located in the Sierra Nevada mountains (Morales-Baquero et al., 2006a). These authors studied the availability of nutrients in Río Seco during years having different climatic conditions (1986, 1996 and 1997). In their study, the DIN:SRP ratio remained roughly constant despite the variability in weather conditions among years. In the present study, the DIN:SRP ratio in 2005 was lower than those measured by Morales-Baquero et al. (2006a) for previous years (Kruskal-Wallis-test; $p<0.05$ ), but no differences were found for 2006 (Kruskal-Wallis-test; $p>0.05$ ). In our study, the drought produced a drastic change in the DIN:SRP ratio and led to a greater degree of $\mathrm{N}$ limitation than any other previous study has reported in Río Seco.

The sharp reduction in the DIN:SRP ratio during 2005 may be explained by the decrease in the annual precipitation values and by the resulting reduction of the external nutrient sources in the catchment area. Under these conditions, other external sources such as atmospheric inputs from Saharan dust could assume greater importance (Morales-Baquero et al., 2001). This source is considered to represent a major source of nutrients (especially P) for many pristine lakes having small catchment areas (Rigler \& Peters, 1995), 
as is the case for Río Seco. In addition, sediment resuspension was very likely more intense in Río Seco during 2005 than during 2006 as a consequence of the shallower water. In this regard, de Vicente et al. (2010b) found that sediment resuspension in Rio Seco caused a high SRP release from sediment particles to the lake water and thereby increased the overall SRP availability in the water column.

In 2006, Río Seco experienced a higher nitrogen concentration and a concomitant increase in the $\mathrm{N}: \mathrm{P}$ ratio, and nutrient limitation was thereby mitigated. Similar nitrogen enrichment has been reported in other aquatic ecosystems during the refilling phase after a drought (Stent, 1981). However, in high mountain lakes it seems that the main cause of the variability in nutrient availability among years having different climatic conditions is an overall control mechanism driven by the trophic web (Morales-Baquero et al., 2006a). Therefore, in dry years like 2005 having low precipitation values, environmental conditions favour internal controls on lake nutrient dynamics. In this study, chlorophyll-a concentrations did not show any difference between years ( $t$ test; $p<0.05$ ), whereas, as mentioned above, nutrient availability differed significantly between years. This lack of differences in chlorophyll- $a$ concentrations, despite variable nutrient limitation, could indicate the existence of additional controls over phytoplankton biomass, zooplankton grazing, for example. In fact, variability in zooplankton nutrient recycling is known to influence nutrient availability, phytoplankton community structure and ecosystem dynamics (Elser \& Urabe, 1999; Elser et al., 1988; 2001).

As recognised by previous studies (Carrillo et al., 1996; Cruz-Pizarro et al., 1998; VillarArgáiz et al., 2001; Pérez-Martínez et al., 2007), the zooplankton community during the study period was quite simple. In general, the calanoid copepod M. laciniatus dominated the community in terms of abundance, but $D$. pulicaria made the greatest contribution to biovolume. The copepod $D$. cyaneus appeared in lower abundance. However, owing to its large individual size, this species represented a significant fraction of the total biovolume during the summer of 2005 and early 2006. During both study years, high biovolume values of zooplankton were observed. Zooplankton community composition can affect nitrogen availability for phytoplankton production through differential consumer-driven nutrient recycling (CNR). CNR has been proposed as a mechanism driving nutrient limitation in lakes (Sterner et al., 1992; Sterner \& Elser, 2002), and the dominance of copepods in the lake during this year with the accompanying high $\mathrm{N}$ demands for somatic growth could account for these results (Sterner et al., 1992). Evidence exists that cladocerans such as Daphnia have a low N:P ratio, a property that results in low rates of $\mathrm{P}$ release (Hessen \& Andersen, 1992). In contrast, calanoids with a high $\mathrm{N}: \mathrm{P}$ ratio could release proportionally more $\mathrm{P}$ (Cruz-Pizarro \& Carrillo, 1991). Thus, calanoid copepods M. laciniatus and $D$. cyaneus comprised $85 \%$ of the total zooplankton density in 2005 . On the contrary, cladocerans showed a higher mean abundance in 2006 than in 2005 (12 and 4 indiv $\mathrm{L}^{-1}$ respectively). In this sense, Carrillo et al. (1996) observed in La Caldera, a nearby Sierra Nevada high mountain lake, that rates of $\mathrm{N}$ and $\mathrm{P}$ release rates by zooplankton depend on $M$. laciniatus growth. Nauplii are organisms with high $\mathrm{N}$ demands and a high proportion of $\mathrm{P}$ because of their elevated growth rates, whereas copepodites and adults have a much lower N:P ratio and release less phosphorus. In Río Seco, the mean abundance of nauplii was higher in 2005 than in 2006 (8 and 5 indiv $\mathrm{L}^{-1}$, respectively). The greater proportion of copepod nauplii observed in Río Seco in 2005 than in 2006 would indicate a greater release of $\mathrm{P}$ relative to $\mathrm{N}$ by zooplankton.

This situation reflects an effective control of zooplankton organisms over the biomass of phytoplankton, especially in the summer of 2005, in which the average biovolume of bacteria and phytoplankton was significantly lower. Thus, in 2005 the A:H ratio exhibited values below 1 . A large part of the total biomass accumulated in the zooplankton fraction. On the other hand, in the summer of 2006 an A:H ratio above 1 reflected an increase in phytoplankton biovolume. During 2005 , strong shortages of N limited primary production in Río Seco, whereas the high zooplank- 
ton biomass produced high predation pressure on phytoplankton. The presence of larger zooplankton organisms during dry years was likely responsible for controlling algal biomass and exemplified predominant "top-down" control. However, a predominant "bottom-up" control of primary producers by nutrients was established during 2006.

Our results indicate that both biotically and abiotically, Río Seco responds differently during drought periods and during wetter periods. Accordingly, long-term monitoring during both dry and wet periods is needed to obtain further insights into the effects of dry/wet periods on the limnological features of Río Seco,

\section{ACKNOWLEDGEMENTS}

This work was supported by project 129/2003 funded by Environmental Ministry (Nature Reserve Autonomous Organisms), and by a grant to FGJ from the University of Jaén. Thanks to the National Park of Sierra Nevada for permission to sample in Río Seco. We would also like to thank the anonymous reviewers and Dra. I. de Vicente for their useful comments.

\section{REFERENCES}

AGUSTÍ-PANAREDA, A. \& R. THOMPSON. 2002. Reconstructing air temperature at eleven remote alpine and arctic lakes in Europe from 1781 to 1997 AD. J. Paleolimnol., 28: 7-23.

APHA. 1995. Standard methods for the examination of water and wastewater. $19^{\text {th }}$ Edition. American Public Health Association, Washington, DC. USA. 1639 pp.

BATTARBEE, R. W., S. T. PATRICK, B. WATHNE, R. PSENNER \& R. MOSELLO. 2001. Measuring and modelling the dynamic response of remote mountain lake ecosystems to environmental change (the MOLAR project). Verh. Int. Ver. Theor. Angew. Limnol., 27: 3774-3779.

CARRILLO, P., I. RECHE \& L. CRUZ-PIZARRO. 1996. Intraspecific stoichiometric variability and the ratio of nitrogen to phosphorus resupplied by zooplankton. Freshwat. Biol., 36: 363-374.

CATALÁN, J., S. PLA, M. RIERADEVALL, M. FELIP, M. VENTURA, T. BUCHACA, L. CA-
MARERO, A. BRANCELJ, P. G. APPLEBY, A. LAMI, J. A. GRYTNES, A. AGUSTÍ-PANAREDA \& R. THOMPSON. 2002. Lake Redó ecosystem response to an increasing warming the Pyrenees during the twentieth century. J. Paleolimnol., 28: $129-145$.

CRUZ-PIZARRO, L. \& P. CARRILLO. 1991. Topdown regulation under different species-specific and size structure grazer assemblages in an oligotrophic lake. Mem. Ist. Ital. Idrobiol., 48: 23-37.

CRUZ-PIZARRO, L. \& P. CARRILLO. 1996. A high mountain oligotrophic lake (La Caldera, Sierra Nevada, Spain). In: Wetlands: a multiapproach perspective. J. J. Cruz-Sanjulián \& J. Benavente (eds.): 111-130. Universidad de Granada. Granada. España.

CRUZ-PIZARRO, L., J. M. CONDE-PORCUNA \& P. CARRILLO. 1998. Diel variation in the egg ratio of Hexarthra bulgarica in the high mountain lake La Caldera (Spain). Hydrobiologia, 387/388: 295-300.

DE VICENTE, I., H. S. HENSEN, F.Ø. ANDERSEN, C. B. HANSEN \& L. CRUZ-PIZARRO. 2010a. Water level fluctuations may decrease phosphate adsorption capacity of the sediment in oligotrophic high mountain lakes. Hydrobiologia, 651: 253 264.

DE VICENTE, I., F. GUERRERO, F. JIMÉNEZGÓMEZ \& L. CRUZ-PIZARRO. 2010b. Settling and resuspended particles: a source or a sink of phosphate in two contrasting oligotrophic high mountain lakes? C. R. Geosci., 342: 46-52.

ELSER, J. J., M. M. ELSER, N. A. MACKAY \& S. R. CARPENTER. 1988. Zooplankton mediated transitions between $\mathrm{N}$ and $\mathrm{P}$ limited algal growth. Limnol. Oceanogr., 33:1-14.

ELSER, J. J. \& J. URABE. 1999. The stoichiometry of consumer-driven nutrient cycling: theory, observations, and consequences. Ecology, 80: 735-751.

ELSER, J. J., L. GUDEX, M. KYLE, T. ISHIKAWA \& J. URABE. 2001. Effects of zooplankton on nutrient availability and seston $\mathrm{C}: \mathrm{N}: \mathrm{P}$ stoichiometry in inshore waters of Lake Biwa, Japan. Limnology, 2: 91-100.

GARCÍA-JURADO, F. 2010. Cambios en la сотиnidad planctónica en lagunas de alta montaña (P.N. Sierra Nevada) frente a fluctuaciones ambientales. Tesis Doctoral. Universidad de Jaén. 200 pp.

GARCÍA-JURADO, F., F. GUERRERO, A. GALOTTI, G. PARRA, L. CRUZ-PIZARRO, I. DE 
VICENTE, F. RUEDA, V. AMORES, J. LUCENA, V. RODRÍGUEZ, P. LEÓN, E. MORENOOSTOS, B. BAUTISTA, J. M. BLANCO, L. ZABALA, J. D. GILBERT \& F. JIMÉNEZ-GÓMEZ. 2007. El plancton de las lagunas de Sierra Nevada: necesidad de estudios transdisciplinares. $M+A, R e-$ vista Electrónica de Medioambiente, 4: 1-10.

HESSEN, D. O. \& T. ANDERSEN. 1992. The algaegrazer interface: Feedback mechanisms linked to elemental ratios and nutrient cycling. Arch. Hydrobiol. Beih. Ergebn. Limnol., 35: 111-120.

MASSANA, R., J. M. GASOL, P. K. BJORNSEN, N. BLACK-BURN, A. HAGSTRÖM, S. HIETANEN, B. H. HYGUM, J. KUPARINEN \& C. PEDRÓS-ALIÓ. 1997. Measurement of bacterial size via image analysis of epifluorescence preparations: description of an inexpensive system and solutions to some the most common problems. Sci. Mar., 61: 397-407.

MORALES-BAQUERO, R., P. CARRILLO, L. CRUZ-PIZARRO \& P. SÁNCHEZ-CASTILLO. 1992. Southernmost high mountain lakes in Europe (Sierra Nevada) as reference sites for pollution and climate change monitoring. Limnetica, 8: 39-47.

MORALES-BAQUERO, R., P. CARRILLO \& L. CRUZ-PIZARRO. 1995. Effects of fluctuating temperatures on the population dynamics of Hexarthra bulgarica (Wiszniewski) from high mountain lakes in Sierra Nevada (Spain). Hydrobiologia, 313/314: 359-363.

MORALES-BAQUERO, R., P. CARRILLO, L. CRUZ-PIZARRO \& P. SÁNCHEZ-CASTILLO. 1999. Nitrogen-phosphorus relationship in high mountain lakes: effects of the size of catchment basins. Can. J. Fish. Aquat. Sci., 56: 1809-1817.

MORALES-BAQUERO, R., C. PÉREZ-MARTÍNEZ \& I. RECHE. 2001. Ecosistemas de alta montaña, las atalayas de la troposfera. Ecosistemas, 10: 1-5.

MORALES-BAQUERO, R., P. CARRILLO, J. BAREA-ARCO, C. PÉREZ-MARTÍNEZ \& M. VILLAR-ARGÁIZ. 2006a. Climate-driven changes on phytoplankton coupling and nutrient availability in high mountain lakes of southern Europe. Freshwat. Biol., 51: 989-998.

MORALES-BAQUERO, R., E. PULIDO-VILLENA \& I. RECHE. 2006b. Atmospheric inputs of phosphorus and nitrogen to the southwest Mediterranean region: biogeochemical responses of high mountain lakes. Limnol. Oceanogr., 51: 830-837.
MURPHY, J. \& J. P. RILEY. 1962. A modified single solution method for the determination of phosphate in natural waters. Anal. Chim. Acta, 27: 3136.

PARK, S., M. T. BRETT, A. MÜLLER-SOLGER \& C. R. GOLDMAN. 2004. Climatic forcing and primary productivity in a subalpine lake: interannual variability as a natural experiment. Limnol. Oceanogr., 49: 614-619.

PÉREZ-MARTÍNEZ, C., J. BAREA-ARCO, J. M. CONDE-PORCUNA \& R. MORALES-BAQUERO. 2007. Reproduction strategies of Daphnia pulicaria population in a high mountain lake of southern Spain. Hydrobiologia, 594: 75-82.

PLANTON, S., M. DEQUE, F. CHAUVIN \& L. TERRAY. 2008. Expected impacts of climate change on extreme climate events. C. R. Geosci., 340: 564574.

PORTER, K. G. \& Y. S. FEIG. 1980. Use of DAPI for identifying and counting aquatic microflora. Limnol. Oceanogr., 25: 943-948.

PULIDO-VILLENA, E., E. ORTEGA-RETUERTA, R. MORALES-BAQUERO \& I. RECHE. 2003. El papel de la escala en los patrones de variación del bacterioplancton en lagunas de alta montaña. Limnetica, 22: 283-287.

PULIDO-VILLENA, E. 2004. El papel de la deposición atmosférica en la biogeoquímica de lagunas de alta montaña (Sierra Nevada, España). Tesis Doctoral, Universidad de Granada. 296 pp.

PULIDO-VILLENA, E., I. RECHE \& R. MORALES-BAQUERO. 2005. Food web reliance on allochthonous carbon in two high mountain lakes with contrasting catchments: a stable isotope approach. Can. J. Fish. Aquat. Sci., 62: 2640-2648.

RIGLER, F. H. \& R. H. PETERS. 1995. Science and limnology. Excellence in Ecology. Vol. 6. Ecology Institute. Oldendorf/Luhe. Germany. 239 pp.

RODIER, J. 1989. Análisis de las aguas. Omega. Barcelona. España. 1059 pp.

ROSE, N. L., E. SHILLAND, H. YANG, T. BERG, L. CAMARERO, R. HARRIMAN, K. KOINIG, L. LIEN, U. NICKUS, E. STUCHLIK, H. THIES \& M. VENTURA. 2002. Deposition and storage of spheroidal carbonaceious fly-ash particles in European mountain lake sediments and catchment soils. Water Air Soil Pollut.: Focus, 2: 251-260.

SÁNCHEZ-CASTILLO, P., L. CRUZ-PIZARRO \& P. CARRILLO. 1989. Caracterización del fitoplancton de las lagunas de alta montaña de Sierra 
Nevada (Granada, España) en relación con las características físico-químicas del medio. Limnetica, 5: $37-50$.

SCHINDLER, D. W., E. J. BEATY, E. J. FEE, D. R. CRUIKSJANK, E. R. DEBRUYN, G. A. FINDLAY, G. A. LINSEY, J. A. SHEARER, M. P. STAINTON \& M. A. TURNER. 1990. Effects of climatic warming on lakes of the central boreal forest. Science, 250: 967-970.

SHINN, J. A. 1941. Colorimetric method for determination of nitrite. Indust. Eng. Chem., 13: 33-35.

SOMMARUGA-WÖGRATH, S., K. A. KOINIG, R. SCHMIDT, R. SOMMARUGA, R. TESSADRI \& R. PSENNER. 1997. Temperature effects on the acidity of remote alpine lakes. Nature, 387: 64-67.

STENT, R. 1981. Grafham water: a discussion of limnological events during the 5-year period 19741978. Freshwat. Biol., 11: 567-578.

STERNER, R. W., J. ELSER \& D. O. HESSEN. 1992. Stoichiometric relationship among producers, consumers and nutrient cycling in pelagic ecosystems. Biogeochemistry, 17: 49-67.
STERNER, R. W. \& J. J. ELSER. 2002. Ecological stoichiometry: the biology of elements from molecules to the biosphere. Princeton University Press. NJ. USA. 584 pp.

STRAILE, D. 2000. Meteorological forcing of plankton dynamics in a large and deep continental European lake. Oecologia, 122: 44-50.

UTERMÖHL, H. 1958. Zur vervollkommung der quantitativen phytolankton-methodik. Mitt. Int. Ver. Theor. Angew. Limnol., 9: 1-39.

VILLAR-ARGÁIZ, M., J. M. MEDINA-SÁNCHEZ, L. CRUZ-PIZARRO \& P. CARRILLO. 2001. Inter-and intra-annual variability in the phytoplankton community of a high mountain lake: the influence of external (atmospheric) and internal (recycled) sources of phosphorus. Freshwat. Biol., 46: 1017-1034.

VILLAR-ARGÁIZ, M., J. M. MEDINA-SÁNCHEZ \& P. CARRILLO. 2002. Microbial plankton response to contrasting climatic conditions: insights from community structure, productivity and fraction stoichiometry. Aquat. Microb. Ecol., 29: 253-266. 